\title{
Analysis of the Impact of Internet Finance on Banking Industry Development
}

\author{
Wang Ping, Zhang Wenjian*, Liu Jiao \\ School of Management, Xi'an University of Science and Technology, Xi'an, China
}

Email address:

zwjian90@126.com (Zhang Wenjian)

${ }^{*}$ Corresponding author

To cite this article:

Wang Ping, Zhang Wenjian, Liu Jiao. Analysis of the Impact of Internet Finance on Banking Industry Development. International Journal of Finance and Banking Research. Vol. 3, No. 4, 2017, pp. 53-56. doi: 10.11648/j.ijfbr.20170304.11

Received: August 19, 2017; Accepted: August 31, 2017; Published: September 22, 2017

\begin{abstract}
With the development of Internet information technology, such as mobile payment, cloud computing and large data, there is a new financial service model - Internet financial model. Analysis of the development of Internet finance found that through the replication of financial functions, and the traditional banking industry to form a competitive situation, and the bank resource allocation, payment and settlement and risk management business impact. In the future development, commercial banks must use the Internet technology platform to promote the transformation in the field of management. In the competition with their own advantages to form a "complementary" integration, in order to promote the improvement of financial services efficiency. In this process, the government actively develop the Internet financial regulatory laws and regulations, improve the lack of supervision of Internet finance.
\end{abstract}

Keywords: Internet Finance, Banking, Development Strategy

\section{Introduction}

Internet finance refers to the financial service providers to the Internet as a platform to provide banks, securities, insurance and other financial services, to the computer network for technical support of the financial activities of the general term [1]. The development of modern financial theory and financial practice has promoted the continuous development of financial intermediary theory. As the product of information network technology and modern finance, with the rapid development of Internet, modern information technology represented by Internet, especially mobile payment, Cloud computing, social networking and search engines, will have a fundamental impact on the human financial model [2]. There is a third type of financial financing model that is different from the indirect financing of commercial banks and is directly related to the direct financing of the capital market. It is called "Internet of financial model" [3]. Xie Ping considers that the Internet financial model is different from the indirect financing of commercial banks, but also different from the direct financing of the capital market, the third financial financing model [4].
From the financing model point of view, the Internet financial model is essentially a direct financing model. However, compared with the traditional direct financing model, the Internet financing model has the characteristics of large amount of information, low transaction cost and high efficiency [5]. As a new type of financial model, Internet finance is to meet the needs of financial functions arising from, and has a more convenient than the traditional financial industry characteristics. Compared with the traditional financial industry, the core function of Internet finance has not changed, but it is static transfer of stable financial function, leading to its competition with the traditional financial industry [6]. At the same time, through the integration of different functions, Internet finance and the emergence of the traditional financial industry integration trend [7]. Therefore, it is of great theoretical and practical significance to strengthen the research of Internet finance in China and to promote the healthy, orderly and sustainable development of Internet finance and banking industry in China.

\section{The Status of Internet Finance}

(1) The China government with Internet finance 
In April 2013, the State Council deployed 19 key research topics in the financial sector, and "Internet Financial Development and Regulation" was one of them. The research group led by the People's Bank, its research views will have a profound impact on the development of China's Internet finance. In August 2013, Internet finance was officially written into two important documents of the State Department The State Council put forward that, "make full use of new technologies and new tools such as the Internet to innovate the network financial service model." in "Opinions on the Implementation of Financial Support for Small and Medium-sized Enterprises". The State Council put forward that,"Promote the Internet financial innovation, regulate the Internet financial services" in "Opinions on Promoting Information Consumption to Expand Domestic Demand" The People's Bank of China gave the Internet financial a positive evaluation, that the Internet financial has advantages such as high transparency, participation in a wide range, intermediate low cost, convenient payment, credit data is more abundant and more efficient information processing, in the second quarter of 2013 monetary policy implementation report, which is the authority of the document that Internet finance entry into the financial aspects for the first time. In December 2013, China Payment and Clearing Association set up the Internet finance Professional Committee, introducing self-regulatory. The State Council promulgated a series of regulations such as "Guidance on Promoting the Healthy Development of Internet finance", "Non-bank payment agencies network payment business management approach"in 2015 , to increase the remediation and supervision of industry Involved in the Internet financial, and make an explanation on Whether the behavior of various types of industry is allowed or not, to prompt the Internet financial back on track.

(2) Financial firms with Internet Finance

Nowadays, most of the formal financial companies are prepared to develop Internet finance, commercial banks also want to build their own P2P platform. Among them, Minsheng Bank is ready to do electronic business platform the of the livelihood;CCB established the "Good financial business"; ICBC established a integrated "payment and financing" business platform;Bank of Communications proposed three-step strategy of the transformation of Internet finance in particular: payment intermediary platform $\rightarrow$ credit intermediary platform $\rightarrow$ credit intermediary platform, said that no longer add any physical network, and they will be ready to turn to the Internet finance[8]. The insurance industry has also accelerated combination with the Internet, Zhong An online property insurance company has been formally established by Alibaba, China Ping An, and Tencent jointly, and received the CIRC license[9]. In addition, Xinhua Insurance and Pacific Insurance set up Internet insurance platform respectively such as Xinhua and Taiping electric business; Guotai Junan replace the retail customer with the Department of Finance, who accesses to Central bank account license, allowing access to the Central bank payment system.

(3) IT firms and mobile operators with Internet finance Mainstream IT companies are actively develping Internet finance. The most typical is Alibaba, who established the Ali financial and Ali small loan; Jingdong officially launched the Jingdong Internet finance, to carry out supply chain financial services, and launched the "Jing Baobei"; Baidu came into the field of financial search, launching "Baidu Baifa"; Tecent aunched the Financial payment and WeChat payment; Sina established a "micro-bank"; Guomei will launch online financial products; Suning launched "yifubao", involved in monetary funds and other investment and financial products. The three mobile operators, China Mobile, China Unicom, China Telecom received a third party payment issued by the People's Bank of China, mobile phone can be used to complete the payment in future [10].

\section{The Impact of Internet Finance on Banking}

The rapid development of Internet finance has enabled academic researchers to rethink the relationship between Internet finance and traditional finance, especially with commercial banks. The idea of "subversion" suggests that Internet finance is likely to replace commercial banks and may lead to the disappearance of banks. The idea of "Fusion theory" suggests that Internet finance is only through the Internet platform to provide financial services. This paper argues that: from the current point of view, Internet finance does not go beyond the scope of "traditional financial functions", while the characteristics of Internet finance is only the impact of commercial banks and cannot have subversive impact. At present, the relationship between Internet finance and commercial banks should be a kind of competitive relationship, and the "carrier" of competition is the financial function possessed by both.

(1) Internet finance's "Resource allocation".

"Resource allocation" is the core function of the traditional banking industry, its core essence is to mobilize savings and optimize the investment, improve the efficiency of the allocation of funds. In the traditional financial industry, commercial banks are important "bridges" to promote the transformation of savings into investment. The biggest feature of Internet financial resources to play a resource allocation function is the two sides directly through the network to match the supply and demand, without any financial intermediary. The resource allocation function of the Internet financial impact on traditional banking through the form of "accelerated financial disintermediation", and this "off the media" occurred in the bank's assets and liabilities side. As the allocation of resources is the core function of the financial industry, so the impact of Internet financial through this function on the banking industry should be the most attention.

First of all, for commercial bank debt business, including bank deposits and various financial management. As China's bank deposit interest rate is determined by the regulatory authorities, and in order to ensure the profits of banks, regulators artificially depressed deposit rates, which is conducive to Internet finance and commercial banks to 
compete for "funding sources". Financial instruments provided by the Internet financial, not only depressed the investment threshold and provided a convenient way to finance for small and medium investors, but also to stimulate the financial awareness of ordinary residents and to promote the development of financial asset management business. Internet finance has an impact on the traditional banking industry first through the bank debtor's "disinfecting" and competition for "funding sources" with commercial banks.

Second, the asset business is the commercial bank's "capital use" platform, is the second link to promote the transformation of savings into investment. Internet finance provides a new way which is different from indirect financing for capitalists, mainly in the capital supply and demand sides do not need to match the information through the financial intermediary, both directly achieve financial transactions on the network platform. In reality, Internet finance has less impact on commercial banks' assets because the main customers of Internet finance generally lack the complete financial statements and often is regarded as high-risk clients by commercial banks and not the main financing objects of commercial banks, and because of the existence of risk problems, some state-owned enterprises or large enterprises will not be through the Internet financial intermediation in the short term, from this point of view, Internet finance is a useful complement to the traditional banking industry.

(2) Internet finance's "Payment settlement".

"Payment settlement" is the basic function of the traditional banking industry, but also the main component of the non-interest income of the banking sector. With the development of the Internet, its customers have grown much faster than commercial banks, which make it possible for the Internet to provide related services similar to the financial industry. So far, the scale of Alipay as the representative of the third party to pay is expanding rapidly, which is the typical model of the current Internet payment, but also the fastest growing financial form in the field of the Internet. The biggest advantage of Internet-based third-party payment is low cost of payment and strong information processing capabilities, which provides customers with a very convenient payment channels. Internet finance "payment settlement" function provides a "intermediary business" similar to the traditional banking industry, on the one hand exerts an influence on the traditional banking industry fee income through the erosion of the intermediary business space, on the other hand the relevant money market funds and financial products can be issued through the Internet channel, which reduces the bank's income on the fund's income.

(3)Internet finance's "Information processing" and "Risk management".

Information is the core element of the process of financial resource allocation, especially the information of the fund demander (such as the borrower in indirect financing, and the issuer of the securities in direct financing). With the Internet platform, Internet finance has a more efficient and less costly information processing than traditional financial models, and is a new type of information processing. For example, Internet finance can use social networks, search engines to retrieve, sort and filter information, to identify information without obligation to disclose, and to achieve efficient information processing with large data systems. Fund supplier can judge the information of fund demander through various information processing platforms provided by the internet on his own. On the surface, the "information processing" of Internet finance is more efficient, but because of the high degree of information sharing, more difficult information screening and more non-standardized data, there are some security risks in information management. With the Internet technology and large data systems continue to improve, Internet financial "information processing" security will continue to improve, which will undoubtedly impact on "information processing" function of the traditional financial model.

\section{Banking Industry's Development Strategy}

Banks have been able to act as a financial intermediary, the most important reason is the information asymmetry. However, the rapid development of IT technology has greatly improved the sharing of customer data on the network and broke the traditional banking industry boundaries and regional structure. In this situation, if the commercial banks want to survive and develop, they must take the initiative to integrate the Internet technology and financial core business deeply and be more involved in the accumulation and digging of data.

First of all, is the cooperation in the field of business. In the field of financing, P2P platform has a large number of customers, but their own funds are limited, and it can not add money through the absorption of deposit, while commercial banks have sufficient funds, so the two sides can achieve win-win cooperation. In the field of payment, whether it is online third-party payment or mobile payment, temporarily are unable to leave the bank and independent, to some extent equivalent to help the bank's payment media functions, extending from the real world to many corners of network world. In this regard, banks should actively cooperate with each other, and increase the signing of cooperation with the electronic business platform and three party payment companies, and jointly expand the coverage areas of payment and settlement. In the field of wealth management, the bank can expand payment cooperation with the third party financial sales platform to earn transaction fee income, at the same time, the bank's own financial products also can be put in the third party financial sales platform for sale.

Second, is the cooperation in the field of management. Bank risk management can learn from P2P, take a bottom-up approach and use large data technology to restore a living customer. In the process management, banks can learn from the Internet business "customer-centric" ideas and practices to design and management process, using the Internet and cloud computing to achieve the effective separation of the former background so that the front focus on customer relationship 
management, the middle direct customer excavation and analysis, the background realize the operation's centralized processing. In terms of data management, the two sides can jointly develop the market through data cooperation.

\section{Conclusion}

In summary, the replication of financial functions of Internet finance has broadened the boundary of financial services, improved the efficiency of resource allocation and the impact on the traditional banking industry, but it cannot subvert the traditional banking industry. The emergence of Internet finance does not provide a new financial model, but rely on the Internet to expand the financial function, but in some core functions such as risk management, the traditional banking industry still has advantages. At present, the Internet is one of the fast-growing industries. The improvement of Internet infrastructure is the main foundation to promote the development of Internet finance. The rapid development of Internet finance can promote the competition of the financial industry and promote the healthy development of the financial system. But for the Internet financial itself, because the customer facing the small micro-enterprises and consumers, the traditional financial system less involved in such customers, so the risk control is still the most important, especially to protect the Internet funds and channels Safety. For the time being, the government has repeatedly expressed its intention to promote Internet financial innovation. Therefore, the development of Internet financial supervision, regulatory rules and regulatory bills is particularly important to make up for the lack of supervision of Internet finance.

In the future development, relying on the Internet financial innovation and traditional banking competition between the more intense, this competitive situation will inevitably lead to both in the development of mutual reference, mutual integration, mutual expansion, through competition to achieve integration, But also through the integration to strengthen competition, will eventually form a healthy financial services environment.

\section{References}

[1] Guan Xiaolin. Internet Financial Model and Its Impact on Traditional Banking [J]. South China Finance, 2013(5): 86-88.

[2] Liu Chao, Liu Li. A Study of System Financial Theory: Comparison of Modern Financial Theory, Behavior Financial Theory and System Financial Theory [J]. South China Finance, 2011 (12): 9-18.

[3] Tan Tianwen, Lu Nan. A Contrastive Analysis of Internet Financial Model and Traditional Financial [J]. China Market, 2013 (46): 101-103. [4].

[4] Xie Ping, Zou Chuanhu. On the Internet-based Finance Model [J]. New Finance Review, 2012(1): 11-22.

[5] Wang Mincheng. An Analysis of the Impact of Internet Finance on Traditional Finance [J]. China Journal of Commerce, 2014(25): 137-138.

[6] Li Jia. The Impact and Fusion of Internet Finance to Traditional Banking Industry-Discussion Based on the view of Function $[\mathrm{J}]$. Journal of Yunnan University of Finance and Economics, 2015(1): 125-130.

[7] Wang Jing. Competition and Reform: the Impact of the Internet Banking on the Traditional Banking Industry [J]. China Business and Market, 2014, 28 (5): 122-126.

[8] Liang Zhang, Shen Fan. How Does the State - owned Commercial Bank Respond to the Challenge of the Internet Financial Model [J]. New Finance, 2013 (7): 47-51.

[9] Xie Ping. The Reality and Future of Internet Finance [J]. New Finance, 2014(4): 4-8.

[10] Xu Yuan. Mobile Internet Finance - Carrier's next Gold Mine [J]. China Telecommunications Trade, 2014(4): 36-37. 